\title{
THE LANGUAGE OF LATIN CURSE TABLETS FROM PANNONIA* A NEW CURSE TABLET FROM AQUINCUM
}

\begin{abstract}
Summary: A lead tablet recently discovered in the eastern cemetery of the Aquincum civil town is of much interest. The tablet which can be dated on archaeological grounds to the late 2nd-early 3rd centuries $\mathrm{AD}$ seems to be a binding curse of a group of men against another group, written in Latin. This curse tablet is especially significant because only five more Latin curses had previously been found in the territory of Roman Pannonia and it supports the inferences that can be deducted from this small collection.
\end{abstract}

Key words: curse tablets, Aquincum, Pannonia, Latin language, formularies

\section{THE CONTEXT}

In 2007 a curse tablet was found in a ditch surrounding a cremation burial in the eastern cemetery of the civil town of Aquincum. Based on the finds, this cemetery, which was used in the whole occupation period, might be one of the most important ones for the Romanized urban middle-class population. The majority of the datable grave-finds came from the $2 \mathrm{nd} \mathrm{c}$. $\mathrm{AD}$, but burials continued in the $3 \mathrm{rd} \mathrm{c.} \mathrm{AD} \mathrm{as} \mathrm{well.}$ A few brick and stone graves were set up in the 4th c. ${ }^{1}$ According to the findings around, this stratum may belong to the late 2 nd, early 3 rd century.

\footnotetext{
* This study was conducted as part of the project OTKA (Hungarian Scientific Research Fund) No. K 62032 entitled 'Computerized Historical Linguistic Database of Latin Inscriptions of the Imperial Age'.

${ }^{1}$ For preliminary reports on the excavations between 2005 and 2007 see LASSÁNYI, G.: Elözetes jelentés az aquincumi polgárváros keleti (gázgyári) temetőjének feltárásáról [Preliminary Report on the Excavation in the Eastern Cemetery (Gas Factory) of the Aquincum Civil Town]. Aquincumi Füzetek 13 (2007) 102-116 and LASSÁNYI, G.: Előzetes jelentés az aquincumi polgárváros keleti (gázgyári) temetỏjében 2007-ben végzett feltárásokról [Preliminary Report on the Excavations Conducted in the Eastern (Gas Factory) Cemetery of the Aquincum Civil Town in 2007]. Aquincumi Füzetek 14 (2008) 64-70. I am grateful to Gábor Lassányi for making the curse tablet available to me.
} 


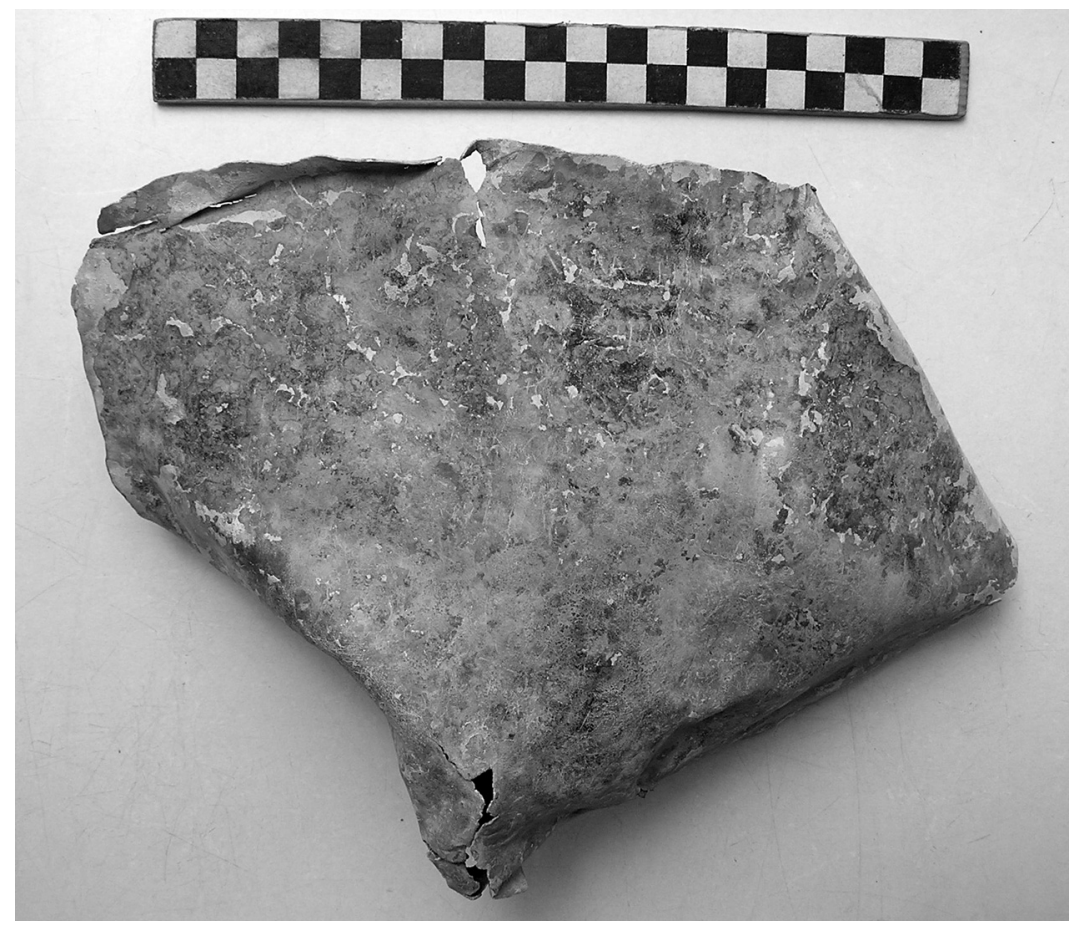

Fig. 1

Since the cemetery was continuously used for burials over a long period and graves frequently intersect each other, it is not surprising that the situation of the tablet (it was turned upside down and creased) showed that the earth was disturbed after the tablet had been inserted. Nonetheless, it is supposed to have been deposited in the cemetery intentionally - as curse tablets were buried underground, usually in a well or a grave, so as to 'make use of' the chthonic powers, or the ghosts of dead $\mathrm{men}^{2}$ - but, lacking adequate information, it cannot be ascertained by whom, when and how the tablet was digged. ${ }^{3}$

\section{THE TABLET}

The grey and white, thin, lead-alloy tablet itself (originally about $24 \times 17 \mathrm{~cm}$ ) is rather crumpled and crushed, making it very difficult to decipher it (fig. 1). (Therefore there are still quite long lacunas in the text, mainly in the last third. ${ }^{4}$ ) But evi-

\footnotetext{
${ }^{2}$ GAGER, J. G.: Curse Tablets and Binding Spells from the Ancient World. New York 1992, 20.

${ }^{3}$ During the 3-year-long excavation no other inscription (except an inscribed gravestone) was found, see LASSÁNYI 2007 (n. 1) 111.

${ }^{4}$ These lacunas are marked by empty spaces inside the text field - a future study may reveal those letters, too.
} 

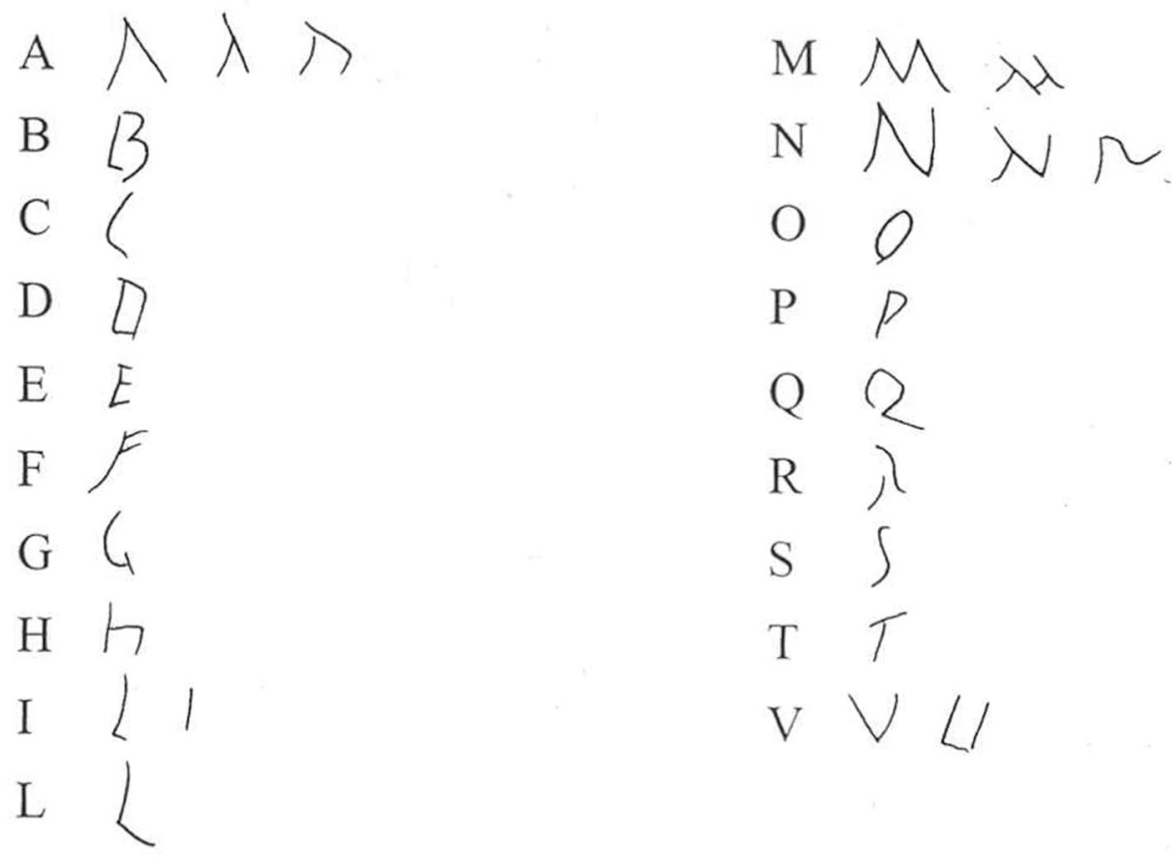

Fig. 2

dently it was not folded up or rolled up - only the soil above might have caused the bendings on the lower part. Some small pieces have broken off and in some places the tablet remains encrusted, but it is nonetheless almost complete and except for the above mentioned parts fully legible with $12+3$ lines of Latin that cover its entire surface apart from a frame. The scribe does not seem to have intended filling up the available space; what is more, smaller lines could later be inserted between the lines. The letters range from 5 to $9 \mathrm{~mm}$ in height - in the first line they are larger than in the others below. They are inscribed clearly and confidently in a rapid capital mixed up in cursive script, which suggests that the man who inscribed them was familiar with the act of writing. Words are not divided from each other, there are no empty spaces between them. All the letters are consequently carved in the same way - there are only a few exceptions (fig. 2). Most of them are majuscules. The letter $A$ was written in the first line by 2 straight lines, but later it is a cursive $A$. Similarly, apart from the first line the letter $U / V$ is almost always rounded, which is rarer than the well known V-type form from stone inscriptions, but can be observed more frequently on softer materials like papyrus or wax tablets. The letter $N$ in the fourth line is carved in a different way from other places - it is also more usual on papyrus or wax tablets. The letter $\mathrm{R}$ is always cursive.

On the left side a very thin vertical line can be observed which might suggest (besides the quite well arranged appearance) that this text was prearranged before scratching or at least the scribe had started to prearrange it (apart from the three 


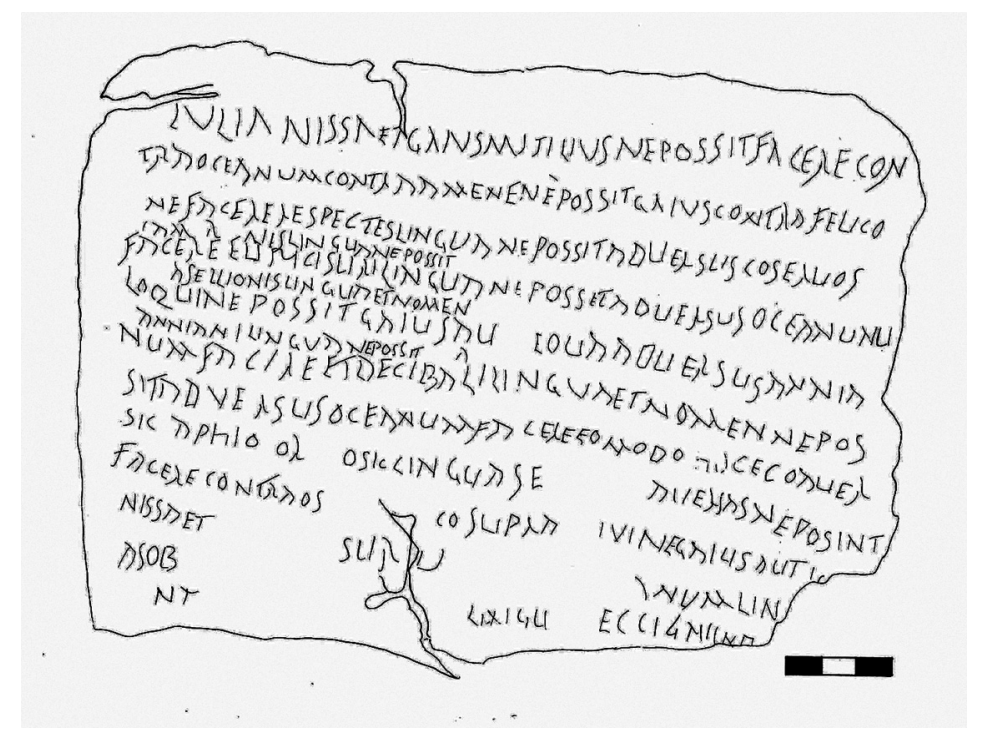

Fig. 3

smaller lines inserted). It is well known that not only stone inscriptions were prearranged, but also military diploms, which were made of lead, too. In some cases, the letters are lightly scratched on the surface, but in others they are more deeply incised. ${ }^{5}$

The text runs as follows (fig. 3):

1 Iulia Nissa et Gaius Mutilius ne possit facere contra Oceanum, contra $A m(o) e n<a>(m)$. Ne possit Gaius contra Felic(i)o-

$3 \mathrm{ne}(\mathrm{m})$ facere. Respectes(!) lingua ne possit adversus coservos

3a [-]am[-]r[---]nis lingua ne possit [---]

4 facere. Eunici Suri lingua ne possit adversus Oceanu $<\mathrm{m}>$

4a Asellionis lingua et nomen [---]

5 loqui. Ne possit Gaius AV[--]EOVA adversus Annia-

5a Anniani lingua ne possit [---] num facere et Decibali(!) lingua et nomen ne pos-

sit adversus Oceanum facere. Eo modo hoc ego aver[--] SIC [-]APHIO[-]OR[--]OSIC lingua [-------] a(d)versas ne pos(s)int facere contra OS[------]CO supra [----]IVI ne Gaius aut [--]

10 Nissa et [------] Surus [------------]anum ling[u--?] as ob [------------------]lingu[a----] ECCIGNI[---] $[---] n t[----------------]$

${ }^{5}$ On military diploms from the Römisch-Germanisches Zentralmuseum in Mainz even traces of ink refer to the carefulness of the scribes in the roman army - preparation and checking are the key to why mistakes are not so frequent on diploms; see ECK, W. - PANGERL, A.: Zur Herstellung der Diplomata militaria: Tinte auf einem Diplom des Titus für Noricum. ZPE 157 (2006) 181-184. 


\section{COMMENTARY AND DISCUSSION}

The text seems to be a curse against a lot of people, a popular subset of the prayers in court, in which a group of men and women asks bindings for another group of people.

The 3 lines inserted under the lines 3, 4 and 5 (marked by $3 a, 4 a, 5 a$ ) are written in smaller, thinner letters. They may have run until the very end of each line, but now only the first part is visible, some traces of scratches further on suggest writings in the whole line. Each line stands alone, they are not continuations of the preceding lines or any of the smaller lines. Why they were written differently is not clear. It would be obvious to suppose that it is a reply to the curse in bigger letters, as Annianus is mentioned again, now as cursed (5a), while in line $5 / 6$ he is a beneficiary of the curse. However, the consistent appearance or style of the writing suggests that it is not a later reply.

The language of the curse is very simple. ${ }^{6}$ A somewhat educated writer would not make much spelling mistakes ${ }^{7}$ - all of which appear in personal names, except the simplification of a geminate in $\operatorname{pos}(s)$ int ${ }^{8}$ The phenomena different from standard Latin are well known from other inscriptions at that time (2nd/3rd c. AD). The wordending $-m$ is not marked twice: $A m(o) e n<a>(m)(1.2)$, Felic(i)o/ne $(m)(1.5 / 6)$, which is a very frequent 'mistake' on inscriptions of the imperial age, as the final $-m$ was hardly perceptible from the 1 st $\mathrm{c}$. BC on. ${ }^{9}$ In the 2nd line inside the name Felicio the second $i$ is maybe omitted because of the scribe's carelessness or for a reason that can be traced back to palatalization changes. ${ }^{10}$ In the name Decebali, the stressed short $E$ has been marked as an $I$, and in the 3rd line the -ae genitive of Respecta has become an -es ending. ${ }^{11}$ If $A M E N E$ (1. 2) is to be read as $A m(o) e n<a>(m)$, the scribe made two more 'mistakes': the $o e>E$ change can be seen on inscriptions at least from the early imperial age, ${ }^{12} \breve{a} \sim \breve{e}$ changes (and $\bar{a} \sim \bar{e}$ as well) appear several times in Pannonian inscriptions, usually in Celtic (or in Greek) personal and geographical names. ${ }^{13}$

The text is made up of short sentences telling who should or should not do anything, or what must happen to them. At least 11 sentences of a similar structure can be distinguished:

1. Iulia Nissa et Gaius Mutilius ne possit facere contra Oceanum, contra Amoenem.

2. Ne possit Gaius contra Felicionem facere.

3. Respectae lingua ne possit adversus coservos facere.

\footnotetext{
${ }^{6}$ For the grammar of curse tablets, see recently: KROPP, A.: Magische Sprachverwendung in vulgärlateinischen Fluchtafeln (defixiones). Tübingen 2008, esp. $243 \mathrm{ff}$.

${ }^{7}$ For standard writing and orthographic mistakes, see Solin, H.: Zur Entstehung und Psychologie von Schreibfehlern in lateinischen Inschriften. In Solin, H. - SAlOMIES, O. - LIERTZ, U.-M. (ed.): Acta colloquii epigraphici Latini Helsingiae 3-6. sept. 1991 habiti. Helsinki 1995, esp. 106.

${ }^{8}$ Herman, J.: Vulgar Latin. Pennsylvania 2000, 46.

${ }^{9}$ HeRman (n. 8) 39-40.

${ }^{10}$ HeRman (n. 8) 42-43.

${ }_{11}^{11}$ HeRman (n. 8) 29-31; Leumann, M.: Lateinische Laut und Formenlehre. München 1977, 419.

${ }^{12}$ LeumanN (n. 11) 74\$b.

${ }^{13}$ FeHÉR, B.: Pannonia latin nyelvtörténete [Die lateinische Sprachgeschichte Pannoniens]. Budapest 2007, 332-333.
} 
4. [-]am[-]r[---]nis lingua ne possit [---]

5. Eunici Suri lingua ne possit adversus Oceanum loqui.

6. Asellionis lingua et nomen [---]

7. Ne possit Gaius [---] adversus Annianum facere.

8. Anniani lingua ne possit [---]

9. Decebali lingua et nomen ne possit adversus Oceanum facere.

10. [---]OSIC lingua [-------] adversas ne possit facere contra OS[---]

11. + Gaius ... Nissa ... Surus [---]num lin(gua) [---]

The structure is quite fixed: the subject is always followed or preceded by the prohibitive form ne possit facere/loqui, though the infinitive can be separated and placed at the end of the line. The preposition of protection is contra in the beginning and at the end of the text, inside the text the preposition adversus or a word from another word class, derived from the same root refers to the cursing persons.

The curse begins with two names, of a certain Iulia Nissa and a Gaius Mutilius. Their names are also mentioned in lines 2, 5,9 and 10-this suggests they may have been the main adversaries of those who prepared this curse. Among the latter an Oceanus is mentioned several times (lines 2, 4 and 7).

All the readable names are well known in the Roman Empire, that is why they are less characteristic. Gaius Mutilius' name (and Iulia Nissa's as well) may refer to the tria nomina of a freeman dropping a part of it. His nomen is quite frequent in Italia, Noricum and Dalmatia, her cognomen occurs not only in the Western European provinces, but in Dalmatia, too. ${ }^{14}$ The names Respecta, Surus, Annianus, Decebalus from the group of the cursed ones sound familiar from the Pannonian inscriptions, moreover an Annianus is mentioned in an inscription from Aquincum. ${ }^{15}$ From the other group all persons' names occur one or several times in Pannonian stone inscriptions. A male Amoenus lived in the western part of the province; $;^{16}$ an Oceanus miles' funerary stele was found near the Danube, south of Aquincum; ${ }^{17}$ and above all a certain Felicio was augustalis in Aquincum in the early 4th century, but there was a potter of the same name, too. ${ }^{18}$

As all names mentioned in the Aquincum curse tablet may occur in Pannonia, there is no argument against its local production. These names may indicate both Roman citizens and slaves. The word coservos in line 3, however, refers to slaves.

No god is mentioned on the curse tablet, but literary sources and earlier evidence inform us that gods were always involved in one way or the other, at least they were invoked orally at the performance. ${ }^{19}$

${ }^{14}$ For details of occurrence see: LÖRINCZ, B.: Onomasticon Provinciarum Europae Latinarum I (A-B) Budapest 1994. II (C-I) Wien 1999. III (L-P) Wien 2000. IV (Q-Z) Wien 2002.

${ }^{15}$ E.g.: Respecta: RIU 1004, RIU 1399 (from the first half of the 3rd c.); Surus: RIU 564 (mid 2nd c.); Aelius Annianus from Aquincum: AE 1937, 194 (188 AD); Decibalus RIU 22.

${ }_{17}^{16}$ CIL III 4254 Szentgyörgy.

${ }^{17} A E$ 1986, 595 Százhalombatta.

${ }^{18}$ RIU 904 Budapest; CIL III 11378, 11379, 11381.

${ }^{19}$ Gager (n. 2) 12-14. 
At least forty magical inscriptions are known from Pannonia on different materials $^{20}$ - or even more, depending on what characters or marks are considered as magical content. Greek is used far more frequently, but characters, letters and words of other Eastern languages (Aramaic, Hebrew, and Coptic) often appear. Nevertheless, there are only five more published Latin curse tablets of the same length and from the same period from Pannonia. ${ }^{21}$

The five curses are different in themes, they fall in three categories: tong tying, concurrency in love and prayer for justice. ${ }^{22}$ The persons mentioned are Roman citizens (AIJ 557 - probably soldiers, as they came from Narbo and Hispania) and slaves (AIJ 432 - Paulina and Firmina were common names among slaves, as well as Greek names like Eudemus: AE 1929, 228).

Regarding the grammar and the appearance of the texts great differences can be observed. The one from Aquincum is well arranged and contains rather few 'spelling mistakes'. On the other hand, mainly the tablets of Siscia (AIJ 557) and Carnuntum $(A E 1929,228)$ teem with such mistakes. On AIJ 557 we may observe reduction in geminated consonants (pes(s)imo), redundant gemination in consonants where they cannot be easily explained, for example in the beginnings of names $(S\{s\} e c u n d o, L\{l\} i$ cinius), but in other cases accent might have caused gemination (Val \{l\}ente). The confusion of $V \sim O, C \sim Q, C \sim G$ can be regarded as usual; word-ending $-m$ and $-s$ are rarely marked. On the Carnuntum tablet only the letter $-t$ - remains in its place from the -nctcluster. The pronoun $q(u) i$ is frequently written without a $-u$ - in inscriptions. Finally confusion in gemination is also vigilant. Technical mistakes made because of the scribe's carelessness or poor education often recur. In short, it is clear from these examples that the people who made use of curses did not require an educated, high-flown style.

Their construction is formulaic: phrases similar to the ones of Aquincum are repeated on AIJ 557: ne contra nos $k$ oq $>$ uiat (!) (1. 4-5); ne possi $<$ nt $>$ contra eum ager $\langle e\rangle$ (1. 15-16), and on AIJ 432 ne quid possit mali facere (1. 3-4). The texts themselves, however, are more diverse - similar sentences are not repeated as many times as on the tablet of Aquincum.

After placing this recently found curse tablet of Aquincum among the previously known ones it is provable this must have been professional's work: the well arranged appearance; the very formulaic language where the only variable is the name of the people involved in the curse; the relatively low number of mistakes ${ }^{23}$ refer to an educated author familiar with the act of writing.

Andrea Barta

${ }^{20}$ FeHÉR, B.: Mágikus nyelvhasználat Pannoniában [The Magical Use of Language in Pannonia (Engl. summary)]. Studia Caroliensia 3-4 (2006) 209-214.

${ }^{21}$ Pannonia Superior: (1) HofFILLER, V. - SARIA, B.: Antike Inschriften aus Jugoslawien (AIJ). Zagreb $1970^{2}$, Nr. 168 - Emona: 2nd half of the 1st c. (2) AIJ 557 - near Siscia: 1st half of the 2nd c. (3) $A I J 432$ - Poetovio: 2nd/3rd c. (4) $A E$ 1929, 228 Carnuntum: turn of the 2nd/3rd c. Pannonia Inferior: (5) KovÁCS, P. - SzABÓ, Á.: Újabb latin feliratos átoktábla Pannoniából [A New Curse Tablet with Latin Inscription from Pannonia]. FolArch 52 (2005-2006) 49-55.

${ }_{22}^{22}$ Categories used by Gager (n. 2) too.

${ }^{23}$ Which can be dated to very early times, so they can even be remnants of an alternative orthography. 